Кузьмак О. М., д.е.н., доцент, професор (Національний університет водного господарства та природокористування, м. Рівне), Кузьмак О. І., д.е.н., доцент, директор (Рівненська філія ПВНЗ «Європейський університет»)

\title{
ПРОБЛЕМИ, НАПРЯМИ ТА МЕХАНІЗМ ПІДВИЩЕННЯ ЯКОСТІ НАДАННЯ ТУРИСТИЧНИХ ПОСЛУГ У КОНТЕКСТІ ЄВРОПЕЙСЬКИХ ВИМОГ
}

В статті досліджено сутність туристичних послуг та їх особливості. Визначено критерії оцінки якості туристичних послуг. Обґрунтовано можливість застосування моделі розривів між очікуваннями споживачів та сприйняттям рівня послуг. Доведено, що дослідження суперечностей, які зумовлюють незадоволення споживачів, сприятимуть прийняттю ефективних управлінських рішень щодо підвищення якості послуг. Обгрунтовано пропозиції щодо підвищення якості туристичних послуг та зниження ресурсоємності, задля чого необхідними є впровадження (інтеграція) процесів менеджменту якості в стратегічний менеджмент підприємства з обов'язковим залученням усіх працівників підприємства та їх підтримки.

Ключові слова: управління, якість, туристична послуга, якість туристичних послуг, очікування споживача, задоволеність споживача.

Постановка проблеми. Розвиток рекреаційно-туристичної сфери для багатьох країн $є$ на сьогодні однією з головних задач. Україна, хоча й розташована в центрі Європи на перехресті транспортних шляхів і має для поступального розвитку своєї рекреаційної сфери сприятливі природно-кліматичні умови, значний історико-культурний потенціал, необхідні людські та матеріальні ресурси, проте значно відстає від більшості європейських країн за рівнем розвитку рекреаційно-туристичних послуг. Такий стан не є нормальним і потребує активізації процесів щодо створення в нашій державі потужної рекреаційної індустрії, яка спроможна задовольняти різноманітні рекреаційні потреби як мешканців України, так і іноземних туристів. Крім того, розвиток вітчизняного туризму супроводжується наявністю глибоких протиріч у його кількісних та якісних параметрах. Однак навіть високі темпи збільшення кількості туристичних підприємств та обсягів туристичних потоків у всіх регіонах України за останні роки не повною мі- 
рою відповідають наявному туристичному потенціалу, а якість і культура туристичних послуг не відповідає прогресивним світовим зразкам. Причини цього пов'язані як з неефективним і нераціональним використанням туристичних ресурсів, обумовлені орієнтацією стратегій пропозиції туристичного продукту на досить примітивні моделі стимулювання споживчої поведінки, так й інерційністю культурних зразків поведінки самих споживачів.

У сучасних умовах ведення туристичного бізнесу багато уваги необхідно приділяти виконанню комплексу заходів, спрямованих на підвищення якості надання туристичних послуг, розроблення дієвих стандартів обслуговування туристів, поліпшення роботи всіх підприємств сфери туризму. 3 метою вдосконалення організації туристичної діяльності більшість країн світу застосовує спеціальні механізми впливу на суб'єкти підприємництва, які виявляються у запровадженні процедур стандартизації, сертифікації туристичних послуг, ліцензування туристичної діяльності.

Аналіз останніх досліджень і публікацій. Питанням теорії та практики розвитку ринку туристичних послуг, проблем якості послуг у туристичній сфері присвячені праці таких іноземних і вітчизняних вчених, як Бедрадіна Г., Бігдан М., Карсекіна В., Качанова В., Кифяк В., Кочерга О., Окрепилова В., Папирян Г., Роглєва Х., Сидоренко І., Ткаченко Т., Шаповалова О., Швець І., Школа І., Шульгіна Л. та ін. Серед західних вчених подібну проблематику в працях розглядали Дж. Кендемпаллі, Б. А. Спаркс, Б. Предау, Дж. Москадо, Е. Лоуз, М. Мекаві та інші.

Незважаючи на активізацію дослідницьких зусиль у згаданих напрямах, необхідно зазначити, що проблеми якісного надання послуг на туристичному ринку, ефективності управлінської роботи в цьому напрямі до цього часу не були предметом комплексного наукового аналізу.

Постановка завдання. Метою статті $€$ розробка теоретичних положень та практичних рекомендацій щодо необхідності дослідження узгодженості вимог до якості пропонованих споживачам послуг у туристичній сфері відповідно до стандартного їх рівня та реальних характеристик.

Виклад основного матеріалу дослідження. Забезпечення високої якості послуг перетворилось у напрямок соціальноекономічного розвитку більшості країн світу. Актуальним для України $€$ прагнення до європейської і світової економіки, яка вимагає засвоєння нових положень ринкової економіки на основі найсучасніших технологій, що забезпечує підвищення якості послуг з орієнтацією на інтереси споживачів. Якість - одна зі складних економічних катего- 
рій, до якої звертаються у випадку вибору механізму задоволення різноманітних потреб, при оцінці кінцевих результатів господарських процесів чи окремих їх операцій, при наданні послуг і стратегії розвитку, резервів підвищення ефективності.

Варто відмітити, що специфікою ринку туристичних послуг $є$ те, що на ньому відбувається купівля-продаж послуг, а не продуктів праці, що мають матеріальну форму. Під послугою в загальному випадку ми розуміємо дію, результатом якої $є$ корисний ефект для споживача. У сфері туристичних послуг корисний ефект полягає у створенні максимально комфортних умов відпочинку. У зв'язку з цим сутність категорії «якість» у сфері туризму має певну специфіку і не може вимірюватися тими ж показниками, що і якість матеріального продукту. Тому в процесі надання послуг суб'єкт туристичного ринку має враховувати характерні особливості процесів надання послуг, що відрізняють їх від уречевленої продукції. До основних характеристик послуг, що відрізняють їх від продукції, можна віднести невідчутність, мінливість, недовговічність та відсутність права власності [1, C. 523].

У найбільш загальному вигляді теоретико-методологічні вимоги до якості послуг подані в системі управління якістю ISO 9000:2000. Згідно з міжнародними стандартами якість послуги розглядається як інтегральна характеристика, узагальнююча сукупність можливостей виконувати вимоги (реалізовувати потреби) замовників та інших зацікавлених сторін. Відповідно до цієї концепції основу якості функціонування сфери туризму має становити якість обслуговування клієнтів на всіх етапах відтворювального циклу між надавачами і споживачами послуг для ефективного функціонування ринкового механізму в галузі.

Як показують дослідження, споживачам необхідні такі послуги, характеристики яких задовольняли б їх потреби та очікування. Ці потреби та очікування відображаються в специфічних умовах на послуги і зазвичай вважаються вимогами споживачів. Вимоги можуть бути встановлені споживачем у договорі про надання послуг або визначені самою обслуговуючою організацією. Ступінь задоволеності споживачів, хоча і не є єдиним показником, що характеризує якість послуги, але являє собою найбільш вагомий критерій.

Прийнятність послуги в кінцевому результаті встановлює споживач. В якості одного з інструментів управління може використовуватися зворотний зв'язок зі споживачами послуг, результатом якої $€$ оцінка якості туристичних послуг. По суті, це інструмент управління формою реалізації головної мети маркетингу - орієнтації на потреби 
споживача. Основним критерієм оцінки якості послуги стає реакція споживача, яка не піддається прямій кількісній оцінці і проявляється як сукупність об'єктивних і суб'єктивних параметрів [2, С. 169].

Так, оцінка послуги передбачає порівняння споживачами особистих очікувань з рівнем сприйняття ними їі якості. Споживчі очікування впливають на задоволеність, оскільки вони створюють "стандарт" для подальшого порівняння і формують думку про якість послуги. Якість відображає з погляду споживача придатність послуги для досягнення його цілей. Задоволеність якістю надаваних послуг буде залежати від того, якою мірою, на думку споживача, вони відповідають своєму призначенню. При цьому до кожного конкретного виду послуг споживач ставить свої специфічні вимоги.

Для туристичних послуг такими вимогами, а отже, показниками якості можуть бути наступні: безпека для життя та здоров'я; своєчасність; надійність; достовірність; доступність; однозначність; повнота відомостей.

Як правило, очікування споживачів не збігаються з дійсністю, тобто можливі різні невідповідності в уявленнях і очікуваннях, які називаються «розривами», і чим вони більші, тим сильніша негативна реакція споживача [3, С. 98]. Тобто під «розривом» розуміється невідповідність уявлень персоналу організації й очікувань споживачів туристичної послуги. Процедура виділення вимог до якості та її характеристик створює необхідні засади для перегляду управлінських завдань та дає можливість з'ясувати роль суб'єктів управління якістю послуг - надавача послуг та споживача.

Тому одним із основних елементів розвитку туристичної сфери в процесі створення й споживання послуг $є$ потреба узгодити суб'єктивні вимоги до якості послуг із стандартним рівнем послуг і реальними характеристиками.

Американські дослідники Е. Парасуріман, В. Зайтхамл і Л. Беррі [4] запропонували модель якості послуг «Модель Gар», яку, безперечно, можна використовувати у сфері туризму. У даній моделі автори визначили основні вимоги до високоякісного сервісу на основі виявлення суперечностей, що зумовлюють незадоволеність споживачів якістю послуг, включаючи наступні протиріччя між:

- очікуваннями споживачів і уявленнями менеджменту щодо рівня якості послуги. Вказані протиріччя виникають через те, що у керівництва підприємства відсутня інформація щодо очікувань споживачів, або інформація, якою вони володіють, не правильна. Причинами появи даного розриву є: низька ефективність проведених маркетингових досліджень; неадекватність зворотного зв'язку між 
споживачами та надавачами послуги; неадекватні комунікації “знизу вгору"; ускладнена багаторівнева структура управління організацією; відсутність досліджень ступеня задоволеності споживачів якістю надаваних послуг [5, С. 150];

- уявленнями менеджменту щодо якості туристичних послуг i вимогами до якості послуг, що зафіксовані в нормативних документах, правилах і порядках. Дане протиріччя виникає через те, що певні очікування споживачів не можуть бути правильно зафіксовані та реалізовані через наявні труднощі у реагуванні на потреби споживачів і, відповідно, відсутності єдиної думки керівництва підприємства щодо якості послуги. Причиною є: нечітке розуміння якості послуги; відчуття нездійсненності надання необхідної послуги; неясність організаційних цілей в управлінні якістю;

- встановленими вимогами до якості сервісу та рівнем туристичних послуг, які фактично надаються. Підприємства розробляють специфікації, що відповідають очікуванням споживачів, проте рівень якості послуг, що надаються, може не відповідати розробленим вимогам. Така ситуація виникає через те, що персонал не спроможний або не хоче надати послугу на необхідному рівні. Причинами цього можуть бути: неоднозначність в розподілі виробничих обов'язків; невідповідність використовуваних технологій виконуваним завданням; недостатнє розуміння персоналом виконуваних функцій; неефективна технологія виконання роботи; недосконалість систем комунікацій і контролю; неякісне навчання персоналу;

- наданими послугами та зовнішніми інформаційними зв'язками, які беруть участь у формуванні уявлення споживачів про отримувані ними послуги. Протиріччя виникають тоді, коли утворюється розрив між тим, що реально пропонує підприємство та тим, яким чином у споживача складається уявлення про якість запропонованих послуг на основі інформації, що поширюється. Причинами протиріччя можуть бути неефективні комунікації між персоналом, що контактує зі споживачами, і співробітниками, які формують рекламну політику; завищені обіцянки підприємства про якість послуг; схильність до переоцінки можливостей та очікувань;

- сприйняттям послуг і очікуваннями щодо сервісу. Розбіжність виникає в тих випадках, коли споживач неправильно сприймає якість послуги. Або ж дані протиріччя виникають при наявності хоча б одного з трьох розривів.

Дані розриви визначають загальний розрив у рівні сервісу туристичних підприємств, для скорочення якого потрібно зменшити величину кожної складової. 3 іншого боку, дана модель не тільки до- 
зволяє побачити процес надання послуги в цілому, а й виявити можливі джерела її незадовільної якості.

В цілому, для усунення суперечностей, що зумовлюють незадоволеність споживачів якістю послуг підприємствам сфери туризму необхідно здійснити всі заходи по інтеграції процесів менеджменту якості в їх стратегічний менеджмент (рисунок). При цьому, як підтримуючі процеси необхідно застосовувати: впровадження інновацій; управління ризиками; залучення інвестицій; оцінку якості послуг споживачами.

Поліпшення результативності та ефективності підприємства сфери туризму, у тому числі системи менеджменту якості, можливе тільки через залучення всіх працівників і їх підтримки [6, С. 325]. Даний процес складається з наступних етапів.

На першому етапі політика в галузі якості надання туристичних послуг розробляється і являє собою цілі, завдання та принципи даної політики.

На другому етапі розроблена політика впроваджується в процеси системи управління якістю, а система менеджменту якості безперервно взаємодіє зі стратегічним менеджментом підприємства і 3 життєвим циклом туристичних послуг.

На третьому етапі політика менеджменту якості підприємства у вигляді нормативів, стандартів, правил, механізмів реалізації доводиться до персоналу всіх рівнів підприємства.

На четвертому етапі визначається компетентність персоналу підприємства, оскільки для виконання завдань із забезпечення якості кожен працівник повинен володіти певними знаннями і навичками, відповідно, повинна бути створена система підвищення якості кадрового складу.

На п'ятому етапі необхідно створити систему взаємозв'язку цілей організації і персоналу для того, щоб персонал розумів, яких цілей йому необхідно досягти, щоб у підсумку підприємство змогло досягти своєї мети в галузі управління якістю туристичних послуг.

На шостому етапі необхідна розробка та впровадження системи мотивації персоналу, яка спонукатиме персонал досягати поставлених перед ним цілей на основі розроблених ключових показників ефективності. 


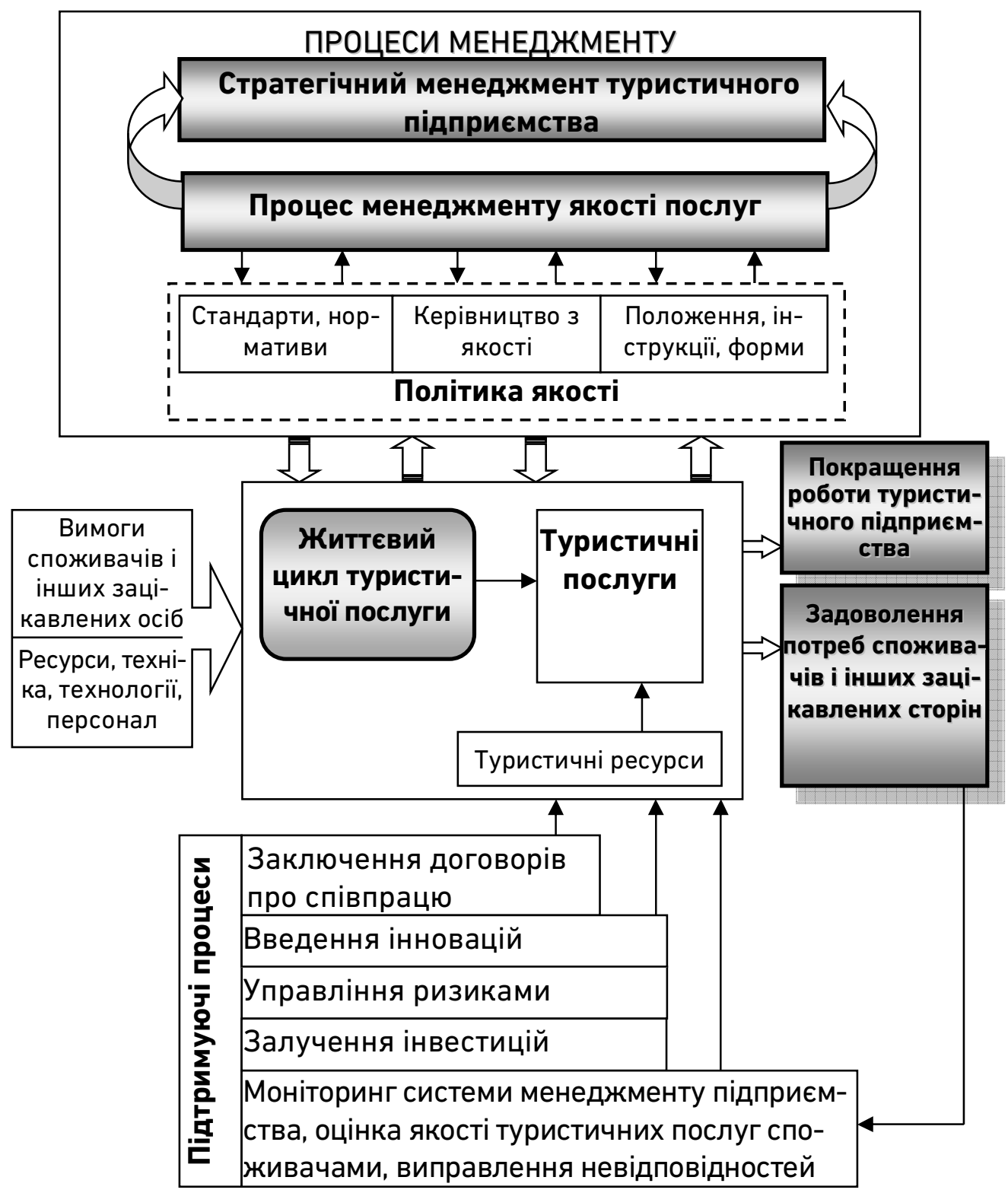

Рисунок. Схема інтеграції менеджменту якості в стратегічний менеджмент туристичних підприємств (складено авторами)

Усунення розривів безумовно сприятиме підвищенню якості туристичних послуг, зниженню ресурсоємності обслуговування, в наслідок чого зростатиме конкурентоспроможність підприємств сфери туризму.

Висновки. Проведені дослідження дають підстави стверджувати, що ситуація, що склалася у туристичній сфері, потребує термінових і дієвих заходів для подолання кризових явищ та інтенсифікації 
виробництва туристичного продукту із забезпеченням необхідної його якості. Оцінка задоволеності споживачів дозволяє поліпшити характеристики туристичних послуг і підвищити якість обслуговування, сприятиме зміцненню конкурентної позиції підприємства на ринку і призведе до встановлення довгострокового взаємовигідного партнерства продавця і покупця. Таким чином, оцінка якості споживчих очікувань виступає одним з важливих інструментів управління маркетингом на підприємствах сфери туризму, забезпечує чіткий зворотний зв'язок зі споживачами послуг і служить основою для формування процесів ринкової взаємодії споживачів і виробників.

Крім того, управління якістю туристичного продукту має проводитись не тільки безпосередньо на підприємствах, які надають послуги, але і на загальнодержавному рівні дана процедура має носити системний характер. Тобто на загальнодержавному рівні повинна функціонувати система стратегічного управління якістю послуг, що надаються, в контексті функціонування туристичного комплексу. Така система являє собою певний організаційно-економічний механізм з чітким розподілом повноважень, нормативно-правовим забезпеченням, економічним підґрунтям, процедурами, процесами та ресурсами, які необхідні для управління якістю туристичного продукту, що виробляється та реалізується на території України [7, С. 102]. Також, державна політика в галузі туризму повинна бути направлена на: вдосконалення правових засад регулювання відносин у галузі; заохочення національних та іноземних інвестицій у розвиток індустрії туризму; сприяння розвитку міжнародного та внутрішнього туризму, зокрема сільського та екологічного; створення сприятливих для розвитку туризму умов шляхом спрощення та гармонізації податкового, митного, прикордонного та інших видів регулювання.

1. Котлер Ф. Основы маркетинга. Краткий курс. М., 2007. 656 с. 2. Андрушків Б. М. Економічна та майнова безпека підприємства і підприємництва. Антирейдерство. Тернопіль : Терно-граф, 2008. 424 с. 3. Руденко Л. Л. Сервисная деятельность. М. : Издательско-торговая корпорация «Дашков и К», 2012. 208 c. 4. Parasuraman A. A., Valarie A. Zeithaml, Leonard L. Berry. Conceptual Model of Service Quality and Its Implications for Future Research. Journal of Marketing. 1985. Vol. 49 (4). P. 41-50. 5. Шимко I. А. Алгоритм прийняття управлінських рішень в умовах ризику (невизначеності). Управління розвитком. 2011. № 20. С. 149-151. 6. Никифоров А. Д., Схиртладзе А. Г. Управление качеством. М. : Студент, 2011. 717 с. 7. Василькевич Л. 0., Кузьмак О.ІІ. Організаційно-економічний механізм підвищення ефективності діяльності туристичних підприємств на основі дослідження моделей поведінки споживачів : монографія. Тернопіль : Терно-граф, 2014. 207 с. 


\section{REFERENCES :}

1. Kotler F. Ocnovy marketinha. Kratkiy kurs. M., 2007. 656 s. 2. Andrushkiv B. M. Ekonomichna ta mainova bezpeka pidpryiemstva i pidpryiemnytstva. Antyreiderctvo. Tepnopil : Terno-hraf, 2008 [in Ukrainian]. 424 c. 3. Rudenko L. L. Servysnaia deiatelnost. M. : Izdatelsko-torhovaia korporatsyia «Dashkov y K», 2012. 208 s. 4. Parasuraman A. A., Valarie A. Zeithaml, Leonard L. Berry. Conceptual Model of Service Quality and Its Implications for Future Research. Journal of Marketing. 1985. Vol. 49 (4). P. 41-50. 5. Shymko I. A. Alhorytm pryiniattia upravlinckykh rishen $v$ umovakh ryzyku (nevyznachenocti). Upravlinnia rozvytkom. 2011. № 20 [in Ukrainian]. 6. Nikiforov A. D., Skhirtladze A. H. Upravlenye kachestvom. M. : Student, 2011. 717 s. 7. Vasylkevych L. 0., Kuzmak 0. I. Orhanizatsiino-ekonomichnyi mekhanizm pidvyshchennia efektyvnosti diialnosti turystychnykh pidpryiemstv na osnovi doslidzhennia modelei povedinky spozhyvachiv : monohrafiia. Ternopil : Terno-hraf, 2014 [in Ukrainian].

Рецензент: д.е.н., професор Мальчик М. В. (НУВГП)

Kuzmak 0. M., Doctor of Economics, Associate Professor, Professor of the of the Department of Finance and environmental economics (National University of Water and Environmental Engineering, Rivne), Kuzmak 0. I., Doctor of Economics, Associate Professor, Director (Rivne Branch of European University, Rivne)

\section{PROBLEMS, DIRECTIONS AND MECHANISM OF THE QUALITY IMPROVEMENT OF TRAVEL PROVIDING SERVICES IN THE CONTEXT OF EUROPEAN REQUIREMENTS}

The study aims to the development of theoretical positions and practical recommendations on the need for coordination of research quality requirements, offered to consumers service level and standard of their actual ratings.

Research has shown that consumers need such services, the characteristics of which would satisfy their needs and expectations. These needs and expectations reflected in the technical specifications for the services and generally considered the requirements of consumers. The degree of satisfaction albeit not the only indicator of the quality of the service, but is the most important criterion. Thus to 
each specific type of service consumer puts their specific requirements.

As a rule, the vast majority of consumers do not match expectations with reality, that there are different possible inconsistencies in representations and expectations, which are called «gaps» and what it is, the stronger the negative reaction of the consumer.

One of the main elements of the development of tourism enterprises in the process of creating and consumption of services is the need to agree the subjective quality requirements, offered customers by tourist service level standard services and its actual performance. In general, to eliminate the contradictions that cause consumer dissatisfaction with the quality of tourist services the company needs to take all measures to integrate quality management processes in the strategic management of the company. However, as the supporting processes must be applied: innovation; risk management; attract investment; assessment of the quality of tourist services by consumers.

Improving the effectiveness and efficiency of the company, including the quality management system, is possible only through the involvement of all employees and support them.

Bridging the gap will increase the quality of tourist services, reduce service capacity resources, and consequently increase competitiveness of tourism enterprises.

Keywords: management, quality, tourist services, quality of travel services, consumer expectations, satisfaction of the consumer.

Кузьмак Е. Н., д.э.н., доцент, профессор кафедры финансов и экономики природопользования (Национальный университет водного хозяйства и природопользования, г. Ровно), Кузьмак О. И., д.э.н., доцент, директор (Ровенский филиал ПВНЗ «Европейский университет»)

ПРОБЛЕМЫ, НАПРАВЛЕНИЯ И МЕХАНИЗМ ПОВЫШЕНИЯ КАЧЕСТВА ПРЕДОСТАВЛЕНИЯ ТУРИСТИЧЕСКИХ УСЛУГ В КОНТЕКСТЕ ЕВРОПЕЙСКИХ ТРЕБОВАНИЙ

В статье исследована сущность туристических услуг и их особенности. Определены критерии оценки качества туристических услуг. 
Обоснована возможность применения модели разрывов между ожиданиями потребителей и восприятием уровня услуг. Доказано, что исследования противоречий, которые обусловливают недовольство потребителей способствовать принятию эффективных управленческих решений, по повышению качества услуг. Обоснованно предложение по повышению качества туристических услуг и снижения ресурсоемкости, для этого необходимым является внедрение (интеграция) процессов менеджмента качества в стратегический менеджмент предприятия с обязательным привлечением всех работников предприятия и их поддержки.

Ключевые слова: управление, качество, туристическая услуга, качество туристических услуг, ожидания потребителя, удовлетворенность потребителя. 